\title{
Childhood Fibroblastic and Myofibroblastic Tumors: A Multicenter Documentation and Review of the Literature
}

\author{
Çocukluk Çağının Fibroblastik ve Miyofibroblastik Tümörleri: \\ Çok Merkezli Bir Dokümantasyon Çalışması ve Literatürün Gözden \\ Geçirilmesi
}

\author{
Ayper KAÇAR ${ }^{1}$, İrem PAKER ${ }^{2}$, Diclehan ORHAN ${ }^{3}$, Aylar POYRAZ $^{4}$, Aylin OKÇU HEPER ${ }^{5}$, Nilüfer ARDA ${ }^{6}$, \\ Esin BODUROĞLU6
}

Department of Pathology, ${ }^{7}$ Ankara Children's Hematology and Oncology Research and Training Hospital, ANKARA, TURKEY, ${ }^{4}$ Gazi University, Faculty of Medicine, ANKARA, TURKEY, ${ }^{5}$ Ankara University, Faculty of Medicine, ANKARA, TURKEY, and ${ }^{6}$ Dr. Sami Ulus Child Diseases Research and Training Hospital, ANKARA, TURKEY, ${ }^{2}$ Department of 2nd Pathology, Dışkapı Yıldırım Beyazıt Research and Training Hospital, ANKARA, TURKEY,

${ }^{3}$ Department of Child Health and Diseases, Pediatric Pathology Unit, Hacettepe University, Faculty of Medicine, ANKARA, TURKEY

\section{ABSTRACT}

Objective: In this study, we aimed to give a documentation of 37 cases of childhood fibroblastic/myofibroblastic tumors retrieved from the archives of 6 reference centers in Ankara along with a comprehensive review on the subject.

Material and Method: A retrospective archive search was carried out for the period between 2006-2010 in 6 reference centers in Ankara covering patients with ages ranging between $0-18$ years. All the tumors categorized under fibroblastic and myofibroblastic group according to World Health Organization criteria were collected.

Results: The study comprised 407 soft tissue tumors in total. Fibroblastic/myofibroblastic tumors constituted 9,1\% (37 cases) of these tumors. According to histopathology; 16 cases were categorized as fibromatosis, 8 cases as inflammatory myofibroblastic tumor, 6 cases as infantile fibrous hamartoma, 3 cases as nodular fasciitis and 2 cases as infantile myofibroblastic tumor/myofibromatosis and 1 case as cranial fasciitis. The only malignant case was an infantile fibrosarcoma.

Conclusion: Infantile fibrosarcoma was lower than reported series and a male predominance was noted. The low incidence of newly described entities as well suggests that these tumors may have been unrecognized.

Key Words: Neoplasms, Fibrous tissue, Pediatric, Infant
ÖZ

Amaç: Bu çalışmada, Ankara'da bulunan 6 referans merkezin arşivi kullanılarak 37 olguluk bir fibroblastik/myofibroblastik tümör serisine ait bir dokümantasyon çalışması ve bu bağlamda bir literatür taraması ve güncellemesi yapılması hedeflenmiştir.

Gereç ve Yöntem: 6 merkezin patoloji laboratuvarları arşivlerinde geriye dönük olarak 2006-2010 yıllarını kapsayacak şekilde 0-18 yaş grubunda arşiv taraması yapılmıştır. Dünya Sağlık Örgütü kriterlerine göre fibroblastik/myofibroblastik tümör grubunda yer alan tüm olgular seriye dahil edilmiştir.

Bulgular: Çalışmada kullanılan seri 407 yumuşak doku tümöründen oluşmaktaydı. Bunların \% 9.1’i (37 olgu) fibroblastik/ miyofibroblastik tümör grubunda idi. Histopatolojilerine göre 16 olgu fibromatozis, 8 olgu inflamatuvar miyofibroblastik tümör, 6 olgu infantil fibröz hamartom, 3 olgu nodüler fasiitis, 2 olgu infantil miyofibroblastik tümör/miyofibromatozis ve 1 olgu kraniyal fasiitis olarak sınıflandırıld. Tek malign olgu infantil fibrosarkom idi.

Sonuç: İnfantil fibrosarkom oranı literatüre göre düşüktür ve tüm olgularda erkek üstünlüğü gözlenmektedir. Ayrıca yeni tanımlanan antitelerin azlığı da bu tümörlerin tanınmasında sorunlar olduğunu düşündürmektedir.

Anahtar Sözcükler: Fibröz doku tümörleri, Pediatrik, Süt çocuğu

\section{INTRODUCTION}

Fibrous tumors comprise $12 \%$ of all soft tissue tumors (STT) in the first two decades and $4 \%$ of all congenital tumors (1). Fibrous tumors have been found to be more

Received : 29.04.2011

Accepted : 07.07.2011 frequent in infants under 1 years old, whereas above this age the neurogenic-myogenic tumors are more common. In this group of tumors, fibromatosis/myofibromatosis constitutes the majority of the cases $(72 \%)$ followed by infantile fibrosarcoma (IFS) (13\%) $(1,2)$.

Correspondence: Ayper KAÇAR

Department of Pathology, Ankara Children's Hematology and Oncology

Research and Training Hospital, Altındağ, ANKARA, TURKEY

E-mail: ayperkacar@yahoo.com Phone: +90 5336557657 
This study is based upon the documentation study of childhood solid tumors conducted by Ankara Pediatric Pathology Working Group in which detailed information about some epidemiologic characteristics of these tumors are provided (3).

In this study, we aimed to focus on fibroblastic/ myofibroblastic tumors (FMT) excluding fibrohistiocytic tumors with variable biological behaviour like plexiform histiocytic tumor, angiomatoid fibrous histiocytoma and neurothekeoma. The results are discussed in the light of the published data paying special attention to some of the recently described and controversial entities. Classification tables according to age and biologic behaviour are also provided (Table I).

Table I: Classification of fibroblastic/myofibroblastic tumors according to age and biologic behaviour

\begin{tabular}{|c|c|c|c|}
\hline Fibrous tumors peculiar to infancy & Biological behaviour & Fibrous tumors of adult type & Biological behaviour \\
\hline Cranial fasciitis & Benign & $\begin{array}{l}\text { Nodular fasciitis, proliferative } \\
\text { fasciitis, ischaemic fasciitis, } \\
\text { ossifying fasciitis; proliferative } \\
\text { myositis, ossifying myositis; } \\
\text { digital osteofibrous } \\
\text { pseudotumor }\end{array}$ & Benign \\
\hline Cardiac fibroma & Benign & $\begin{array}{l}\text { Other fibromas (desmoplastic } \\
\text { fibroma, nerve and tendon } \\
\text { sheath fibroma) }\end{array}$ & Benign \\
\hline Fibromatosis colli & Benign & $\begin{array}{l}\text { Desmoid type fibromatosis } \\
\text { (superficial and deep) }\end{array}$ & $\begin{array}{l}\text { Intermediate } \\
\text { (locally aggressive) }\end{array}$ \\
\hline Fibrous hamartoma of infancy & Benign & Cellular fibrous histiocytoma & Benign \\
\hline Calcifying fibrous tumor & Benign & Myxoma & Benign \\
\hline Juvenile hyaline fibromatosis & Benign & Solitary fibrous tumor & $\begin{array}{l}\text { Intermediate } \\
\text { (rarely metastasizing) }\end{array}$ \\
\hline $\begin{array}{l}\text { Congenital and acquired muscular } \\
\text { fibrosis }\end{array}$ & Benign & $\begin{array}{l}\text { Dermatofibrosarcoma } \\
\text { protuberans }\end{array}$ & $\begin{array}{l}\text { Intermediate } \\
\text { (rarely metastasizing) }\end{array}$ \\
\hline Infantile fibromatosis & $\begin{array}{l}\text { Intermediate } \\
\text { (locally aggressive) }\end{array}$ & $\begin{array}{l}\text { Angiomatoid fibrous } \\
\text { histiocytoma }\end{array}$ & $\begin{array}{l}\text { Intermediate } \\
\text { (rarely metastasizing) }\end{array}$ \\
\hline Infantile fibrosarcoma & $\begin{array}{l}\text { Intermediate (rarely } \\
\text { metastasizing) }\end{array}$ & Adult type fibrosarcoma & Malignant \\
\hline Giant cell fibroblastoma & $\begin{array}{l}\text { Intermediate (locally } \\
\text { aggressive) }\end{array}$ & $\begin{array}{l}\text { Low grade fibromyxoid } \\
\text { sarcoma }\end{array}$ & Malignant \\
\hline Gardner associated fibroma & Benign & $\begin{array}{l}\text { Sclerosing epitheloid } \\
\text { fibrosarcoma }\end{array}$ & Malignant \\
\hline Infantile myofibromatosis & Benign & $\begin{array}{l}\text { Low grade myofibroblastic } \\
\text { sarcoma }\end{array}$ & $\begin{array}{l}\text { Intermediate } \\
\text { (rarely metastasizing) }\end{array}$ \\
\hline Infantile digital fibromatosis & Benign & Synovial sarcoma & Malignant \\
\hline Calcifying aponeurotic fibromatosis & Benign & Rhabdomyofibrosarcoma & Malignant \\
\hline $\begin{array}{l}\text { Juvenile nasopharyngeal } \\
\text { angiofibroma }\end{array}$ & $\begin{array}{l}\text { Intermediate (locally } \\
\text { aggressive) }\end{array}$ & & \\
\hline $\begin{array}{l}\text { Cerebriform fibrous proliferation } \\
\text { (proteus syndrome) }\end{array}$ & Benign & & \\
\hline Gingival hereditary fibromatosis & Benign & & \\
\hline Lipofibromatosis & $\begin{array}{l}\text { Intermediate (locally } \\
\text { aggressive) }\end{array}$ & & \\
\hline Inflammatory myofibroblastic tumor & $\begin{array}{l}\text { Intermediate (rarely } \\
\text { metastasizing) }\end{array}$ & & \\
\hline Plexiform fibrohistiocytic tumor & $\begin{array}{l}\text { Intermediate (rarely } \\
\text { metastasizing) }\end{array}$ & & \\
\hline
\end{tabular}




\section{MATERIAL and METHODS}

A retrospective archive search was carried out for the period between 2006-2010 in 6 reference centers in Ankara* covering patients with ages ranging between 0-18 years. Histopathologic diagnoses were checked case by case and all the tumors under fibroblastic and myofibroblastic group were collected in order to analyze these tumors by using parameters of age, sex, localization, histopathologic diagnosis and biologic behaviour. The age groups were formed as 0-1 years, 1-4 years, 4-10 years, and 10-18 years. Classifications for diagnosis and tumor behaviour were established according to World Health Organization (WHO) criteria.

\section{RESULTS}

The study comprised 407 STTs in total. The breakdown of the cases with respect to the age groups was as follows: $0-1$ years: 44 ; $1-4$ years: $79 ; 4-10$ years: $119 ; 10-18$ years: 164 cases. Distribution of the whole STT cases according to histopathology is provided in Table II. FMT constitute 9,1 $\%$ (37 cases) of these tumors. There were 31 males (83\%) and 6 females (17\%) in this group. The data on age was available for all patients. There were 9 FMT (20,5\%) in $0-1$ years group. There was no newborn case in this group, with the youngest patient being 2 months old. The number of FMT cases in the other age groups were as follows: 1-4 years: 7 cases $(8,9 \%), 4-10$ years: 10 cases $(8,4 \%), 10-18$ years: 10 cases $(6,1 \%)$.

Table II: Distribution of 407 pediatric soft tissue tumors in 1362 cases

\begin{tabular}{|l|l|}
\hline $\begin{array}{l}\text { Benign } \\
\text { soft tissue } \\
\text { tumors } \\
(321)\end{array}$ & $\begin{array}{l}\text { Vascular tumors (179) } \\
\text { Lipomatous tumors (43) } \\
\text { Fibroblastic/myofibroblastic tumors (36) } \\
\text { Peripheral nerve sheath tumors (32) } \\
\text { Fibrohistiocytic tumors (31) }\end{array}$ \\
\hline $\begin{array}{l}\text { Malignant } \\
\text { soft } \\
\text { tissue } \\
\text { tumors } \\
(86)\end{array}$ & $\begin{array}{l}\text { Rhabdomyosarcoma (56) } \\
\text { Malignant peripheral nerve sheath tumors (7) } \\
\text { Fibromyxoid sarcoma (7) } \\
\text { Leiomyosarcoma (6) } \\
\text { Dermatofibrosarcoma protuberance (3) } \\
\text { Epithelioid hemangioendothelioma (3) } \\
\text { Synovial sarcoma (3) } \\
\text { Infantile fibrosarcoma (1) }\end{array}$ \\
\hline
\end{tabular}

According to histopathology; 16 cases were categorized as fibromatosis (2 fibromatosis colli, 1 superficial and 13 deep fibromatosis). There were 4 females and 12 males, age ranges from 2 months to 17 years (median age 8 years). The localizations of the tumors were as follows: 3 upper extremity, 3 lower extremity, 3 thoracic wall, 3 glutea, 2 neck, 1 frontal region, 1 mandibula (Figure 1A, B).

There were 8 cases diagnosed as inflammatory myofibroblastic tumor (IMT) histopathologically (Figure $2 \mathrm{~A}-\mathrm{C}$ ). All but one case was male. The age of the patients ranged between 2-12 years (median age 7.2 years). The localizations were as follows: 2 intestine, 1 rectum, 1 thoracic wall, 1 lung, 1 pelvic soft tissue, 1 cranium.

Six cases were diagnosed as infantile fibrous hamartoma (IFH) (Figure 3). All the cases were male with age ranging between 5-17 months (median age 1 year). Two cases were
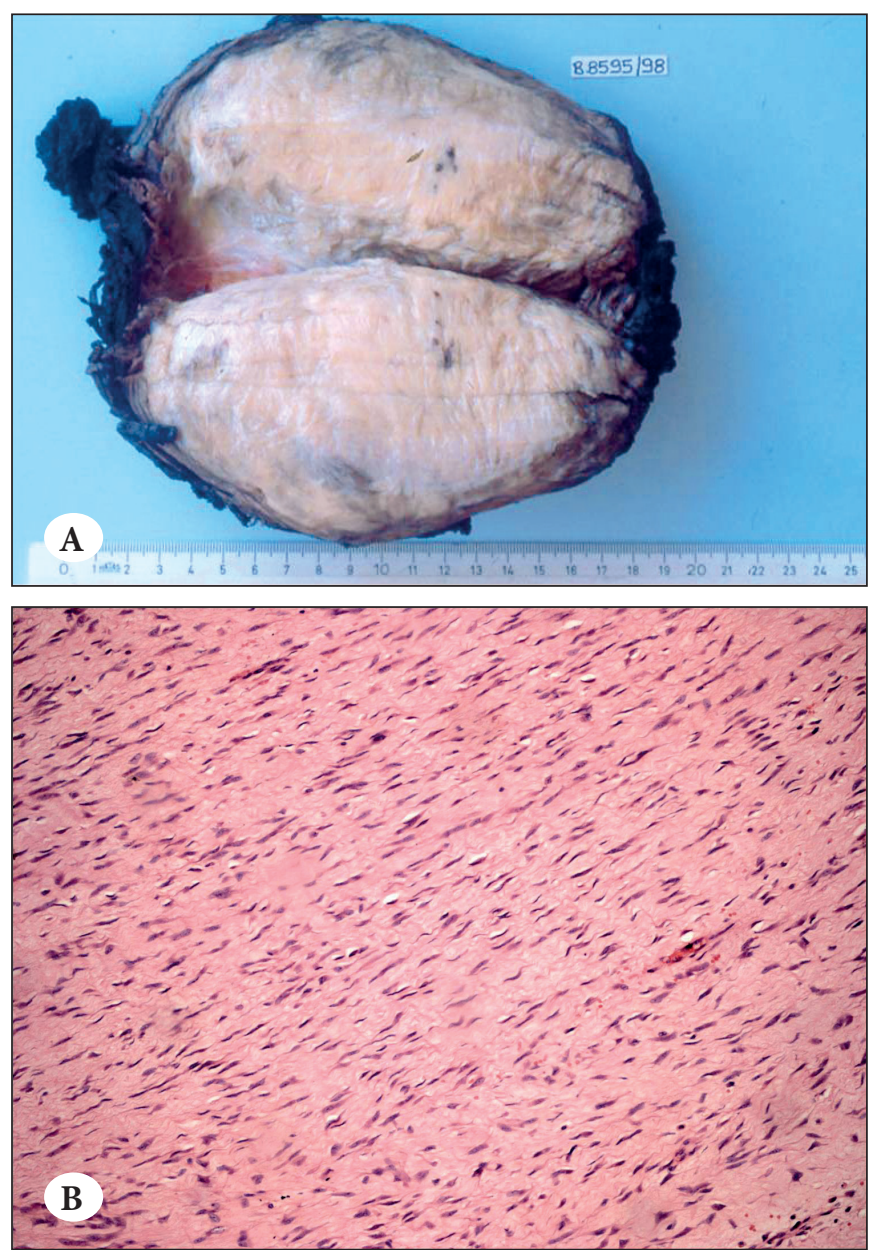

Figure 1: A) Well circumscribed solid white-cream mass with fibrillary cut surface, B) Proliferation of bland (myo)fibroblasts arranging in fascicules in a collagen rich extracellular matrix.

${ }^{*}$ Hacettepe University, Pediatric Pathology Unit; Pathology Department of Gazi University, Pathology Department of Ankara University, Dr. Sami Ulus Child Diseases Research and Training Hospital, Dışkapı Yıldırım Beyazıt Research and Training Hospital, and Ankara Child Diseases, Hematology and Oncology Hospital. 
localized in the axilla, 1 in the neck, 1 in the thoracic wall, 1 in the sacral region and 1 in the scrotum.
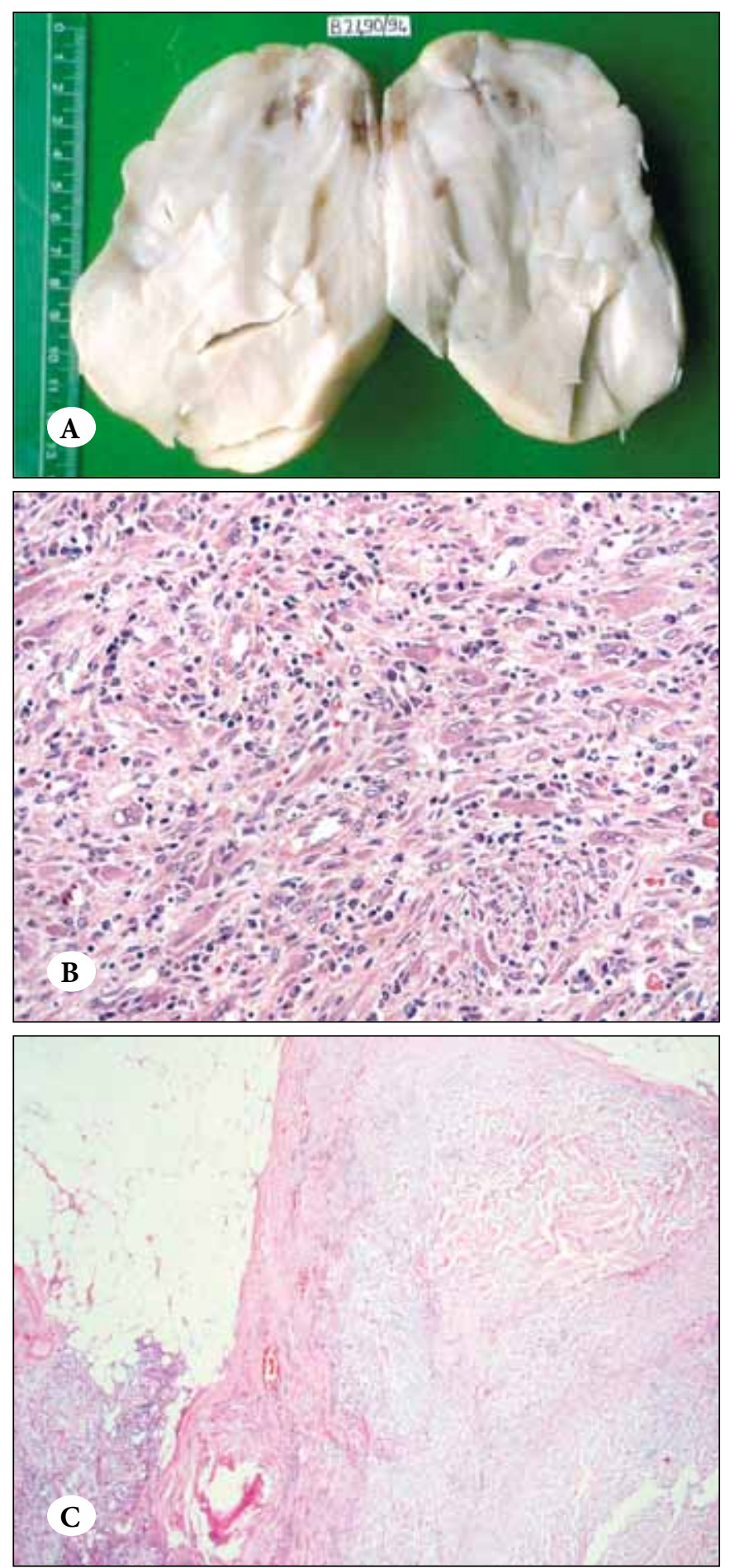

Figure 2: A) White-cream solid mass. Note that the mass lack the fasciculated cut surface, B) IMT showing cellular pattern, composed of spindle cells with voluminous nuclei intermingled with inflammatory cells and ganglion like cells, C) IMT with a sclerotic pattern in the thigh of a ten year-old girl.
There were 3 nodular fasciitis (NF) cases, all males with ages ranging between $5-13$ years (median age 10 years). Two cases were localized in the cranium and upper extremity while the localization was unknown for 1 case.

Two cases were diagnosed as infantile myofibroblastic tumor/myofibromatosis (a 1-year-old male and an 18-yearold female). The tumors were localized in the liver and lower extremity.

The single cranial fasciitis (CF) case was 1 year old male with orbita localization.

The single malignant case of our series was a 4-month-old male IFS case who had presented with an upper extremity localized mass (Figure 4).

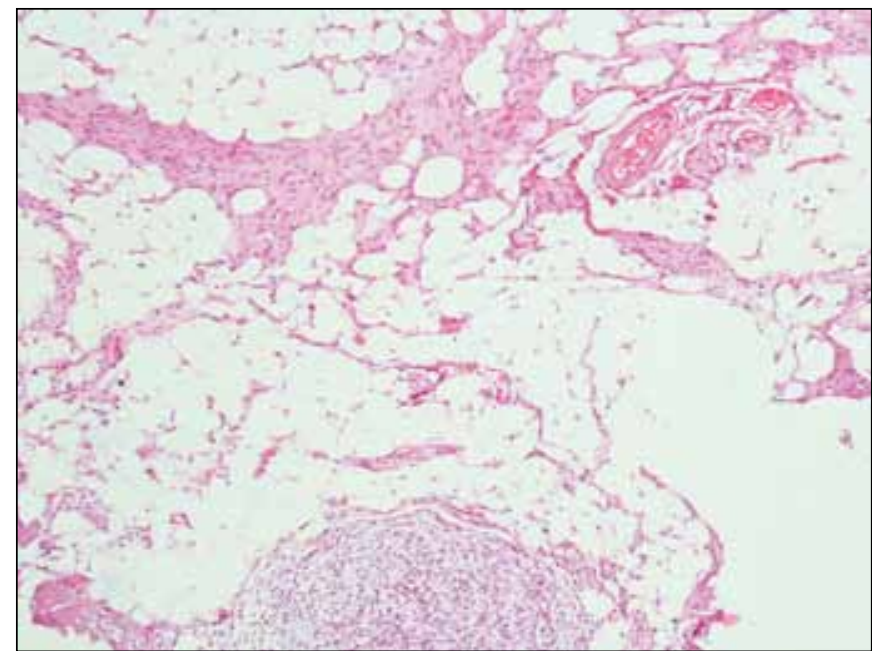

Figure 3:IFH in the axillary region of an 18 month-old male. Note the intermingling of primitive myxoid tissue, collagenous spindle cell areas and the fat.

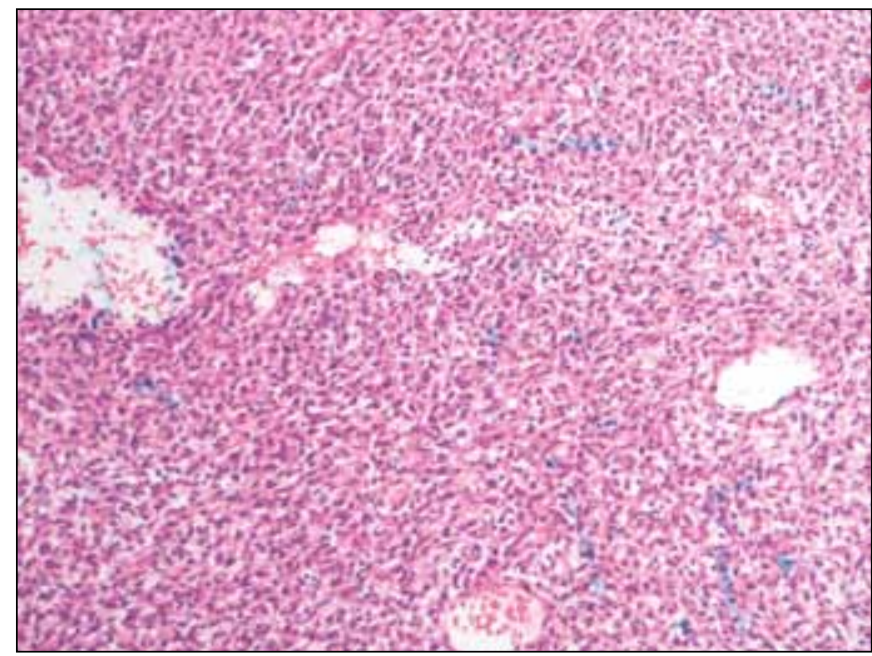

Figure 4: Densely cellular neoplasm of intersecting fascicules of scattered ovoid and spindle cells. 


\section{DISCUSSION}

Childhood FMT can be classified according to histology, age and biologic behavior (Table I). Fibrous tumors that are peculiar to infancy are listed in Table I, and in general have no clinical or morphological counterpart in adult life and pose a special problem in diagnosis because of their rarity. Their unusual microscopic features fail to accurately reflect their biological behavior and may be mistaken for evidence of malignancy and cause unnecessary and excess therapy (4). Adult type FMT are listed separately and are rarely seen in this population. Most of the pediatric FMT fall into the benign category. There are limited series concerning these tumors in the literature (1). Although this study was designed to document these tumors in the Ankara region, taking into account that the contributing centers to this study are among the biggest referral centers in the country, the study can be assumed to represent wider data about Turkey. Our data showed that FMT comprise $9.1 \%$ of all childhood STTs. The incidence was higher in infants (0-1 years) with $20.5 \%$ of STTs for this age and descended slowly with the increasing age. Although myofibromas constitute significantly a smaller part of this group with only two cases, in accordance with the literature, the fibromatosis/ myofibromatosis group constituted the majority of our cases in this group (43.2\%), followed by IMT (21.6\%), IFH (16.2\%) and NF (8.1\%) respectively. We had a single case of CF $(2.7 \%)$ and a single malignant case of IFS (2.7\%). The incidence of IFS in our study was low compared to the published data (2). According to gender, 31 of 37 children were male $(83.8 \%)$ which was a striking finding in the present study. In the series of Dr. Coffin, the ratio for male/female was 1.8/1 and the median age was 7 years (2). While the median age was almost compatible with the literature (5.2 years) in our series, the male predominance $(\mathrm{m} / \mathrm{f}=4.8 / 1)$ was significant. The biggest FMT series in the literature comprised 103 patients, and the male/female ratio in this study was $1.8 / 1$ (2). Although this result already indicates a certain male tendency, this data is not verified with further series in the literature. Making a comparison regarding this bias is not straightforward since this group of tumors is not documented widely in the literature. On the other hand, our results showed a distinctive predominance of male gender in our series. In our opinion, this data should be verified by further documentations in the literature.

We also note that some fibroblastic entities peculiar to childhood such as Gardner-associated fibromas, inclusion body fibromatosis, juvenile hyaline fibromatosis and newer entities like lipofibromatosis were consistently lacking in our series. Some other entities such as IFS (1 case) and CF (1 case) had lower incidences when compared to the published data, while NF was much more common (3 cases). This led us to consider that childhood FMT could have been unrecognized and diagnostic experience related to these tumors might be still lacking. In our opinion these data should be reevaluated in larger series with a central review carried by the experts in the field.

Cranial fasciitis is the only reactive fibroblastic lesion that is peculiar to infancy. Other types of fasciitis are uncommon in children. It is similar morphologically and histologically to its adult counterpart NF, except for its occurrence in infants under 2 years old. It is typically well circumscribed and the histology is similar to NF with variably myxoid and hyalinized matrix occasionally with foci of osseous metaplasia. Nodular fasciitis is rare in children. Both CF and NF are completely benign, probably reactive lesions cured with local excision. Intravascular fasciitis is a rare form of NF with a young age predilection. It has a benign course with rare recurrence (5). Proliferative fasciitis (PF) and myositis are principally lesions of adults. A rare variant of $\mathrm{PF}$ is described in children (6).

Gardner-associated fibroma and cardiac fibroma are the most frequent types of fibroma encountered in childhood. Clinically they are defined as solitary or multiple superficial and soft tissue fibromas associated with Gardner's syndrome (70-90\% of cases) and desmoid fibromatosis (18-45\% of cases) with a predilection for childhood and adolescence that is caused by the mutation of the APC gene on chromosome $5(4,7,8)$.

Table III: Cellular infantile fibromatosis: differential diagnosis with infantile fibrosarcoma

\begin{tabular}{|l|l|l|}
\hline Features & Infantile Fibromatosis & Infantile Fibrosarcoma \\
\hline Cellularity & variable & moderate to high \\
\hline Herringbone pattern & absent & usually present \\
\hline Mitotic figures & rare & few to many \\
\hline Hemorrhage & absent & often present \\
\hline Necrosis & absent & often present \\
\hline $\mathrm{t}(12 ; 15)(\mathrm{p} 13 ; \mathrm{q} 25)^{\star}$ & absent & present \\
\hline
\end{tabular}

${ }^{*}$ see reference (18). 
Infantile myofibromatosis is the most common fibrous disorder of infancy and childhood. Principally it is a tumor of infancy as most of the cases are detected at birth or under 2 years. There are familial cases reported in the literature (9). Clinicopathologic similarities between infantile hemangiopericytoma (HPC) and infantile myofibromatosis have suggested that both lesions might belong to the same spectrum of disease and probably are of a pericytic nature (10). Today it is widely accepted that infantile HPC represents the immature form of infantile myofibroblastic tumor, and is hence considered an infantile form of myofibromatosis (11). The prognosis is excellent. Congenital cases with visceral involvement have a poor prognosis and the mortality is about $75 \%$. Rare spontaneous regression is reported (12).

Juvenile fibromatosis is a designation that has been applied to a morphologically diverse group of locally aggressive STTs. This type of infantile fibromatosis probably represents the same spectrum of disease with the recently described lipofibromatosis $(4,13)$. Superficial forms of adult type fibromatosis are extremely rare in childhood. Infantile fibromatosis (IFM) is no longer retained in the new WHO classification system as a term; instead, lipofibromatosis is present in the classification to cover this tumor group. Thus, lipofibromatosis is a recently-described entity comprising part of the spectrum of old infantile fibromatosis terminology (13). It typically originates in the skeletal muscle as an ill-defined, slowly growing, solitary mass. It consists of mature adipose tissue as an integral component and intersecting trabeculae comprising a spindle cell component. Fat typically makes up more than $50 \%$ of the specimen (13). The key proliferative element is the fibroblastic component and non-destructive recurrence is frequent when incompletely excised. Occasional nonrecurrent cases are reported, despite the positive surgical margins (14). This phenomenon is attributed to lesional maturation analogous to that described in other benign fibrous and lipomatous tumors (13).

Fibrosarcoma in newborns, infants and small children bears some resemblance to adult fibrosarcoma, but it must be considered as a separate entity because of its markedly different clinical behaviour as well as its distinctive molecular alterations. IFS constitutes $12 \%$ of soft tissue malignancies in children and is morphologically and genetically related to congenital mesoblastic nephroma (15). It presents as a rapidly growing mass of large size that arises in the deep tissues of extremities (70\%), followed by the trunk and head and neck (16). Histologically, it is an infiltrative, densely cellular neoplasm of intersecting fascicules of primitive ovoid and spindle cells with a herringbone pattern. Increased mitosis, little pleomorphism, variable collagen and scattered chronic inflammatory cells are common. Necrosis, hemorrhage, dystrophic calcification, extramedullary hematopoiesis may be encountered. The diagnostic features are the uniformity of the cells, the solid growth pattern and fascicular arrangement with a lymphocytic infiltrate, and the absence of specific differentiation indicative of other tumor types. There are reports about existence of composite tumors with features of myofibromatosis, infantile HPC and IFS and a histogenetic relationship between these entities is suggested (17). A cellular form of desmoid type fibromatosis may pose a problem in the differential diagnosis. Table 3 shows some useful criteria for the distinction of these tumors (18). Tumors can start with the appearance of one and recur as the other $(19,20)$. There is compelling evidence that some cases of IFM carry some similar cytogenetic changes with IFS $(21,22)$.

IMT is a fibroblastic tumor occurring principally in the viscera and soft tissues of children and young adults with a mean age of 10 years that has an intermediate biologic potential but which usually follows a benign clinical course. Today IMT is accepted as a distinct entity with clinical, pathological and molecular characteristics (23). Many have been associated with aggressive local or distant behaviour that has resulted in some deaths $(4,24)$. In addition, some tumors show aberrations of the ALK-1 gene supportive of a neoplastic process (25-28). In children differential diagnosis should be done basically with embryonal rhabdomyosarcoma (RMS), CF, extrapulmonary solitary fibrous tumor, solitary myofibroma and fibromatosis. Histopathology is essentially non-predictive in reflecting biologic behavior. Spontaneous regression has been reported in some cases.

Childhood fibroblastic and myofibroblastic tumors comprise an evolving area with many overlapping features. Pediatric fibroblastic tumors generally have a better overall prognosis than their adult counterparts. The critical differential diagnoses not to be missed can be summarized as follows: proliferative fasciitis vs RMS; ossifying fasciitis/ myositis/periostitis vs ostesarcoma; IFS vs synovial sarcoma, spindle cell RMS, rhabdomyofibrosarcoma and malignant peripheral nerve sheath tumor. A useful immunohistochemical panel for these tumors might include CD34, ALK, actin, desmin, $\beta$-catenin, h-caldesmon, calponin, S100, factor XIIIa and CD68.

It should be taken into account that histology alone is not predictive and immunohistochemical and cytogenetics do not aid too much in the differential diagnosis of these tumors. An accurate diagnosis can be achieved by appropriate evaluation of clinical presentation, localization, age and morphology together. 
In conclusion, our findings were similar to the original observations made by Dr. Coffin and his colleagues (2), with the exceptions of higher male incidence along with a lower incidence in myofibroma and IFS cases.

\section{ACKNOWLEDGEMENT}

We would like to express our sincere thanks to Prof Dr. Sergülen Dervişoğlu and Prof. Dr. Erdener Özer for their valuable review on the manuscript.

\section{REFERENCES}

1. Coffin CM, Boccon-Gibod L: Proliférations fibroblastiques et myofibroblastiques de l'enfance et de l'adolescence. Ann Pathol 2004, 24:605-620

2. Coffin CM, Dehner LP: Fibroblastic and myofibroblastic tumors in children and adolescents: A clinicopathologic study of 108 examples in 103 patients. Ped Pathol 1991, 11:559-588

3. Kaçar A, Paker I, Akçören Z, Güçer S, Kale G, Orhan D, Talim B, Poyraz A, Uluoğlu Ö, Okçu Heper A, Apaydın S, Arda N, Boduroğlu E, Albayrak A, Alper M, Arıkök AT: Documentation of pediatric solid tumors in Turkish children: a multicenter study. (epub ahead of print) World J Pediatr 2011

4. Weiss SW, Goldblum JR: Soft tissue tumors. 5th ed., Philadelphia, Mosby Elseviers, 2008, 257-302

5. Patchefsky AS, Enzinger FM: Intravascular fasciitis: a report of 17 cases. Am J Surg Pathol 1981, 5:29-36

6. Meis JM, Enzinger FM: Proliferative fasciitis and myositis of childhood. Am J Surg Pathol 1992, 16:364-372

7. Fletcher CDM, Krishnan Unni K, Mertens F: Pathology and Genetics: Tumors of Soft Tissue and Bone. Lyon, IARC Press, 2002

8. Wehrli BM, Weiss SW, Yandow S, Coffin CM: Gardner associated fibromas (GAF) in young patients: a distinct fibrous lesion that identifies unsuspected Gardner syndrome and risk for fibromatosis. Am J Surg Pathol 2001, 25:645-651

9. Alvarez-Rodrigez FJ, Baeza-Herrera C, Garcia-Cabello LM, Godoy-Esquivel AH, Atzin-Fuentes JL: Fibromatosis infantile. Report of an aggressive disease. Cir Cir 2006, 74:269-272

10. Mentzel T, Calonje E, Nascimento AG, Fletcher CD: Infantile hemangiopericytoma versus infantile myofibromatosis. Study of a series suggesting a continuous spectrum of infantile myofibroblastic lesions. Am J Surg Pathol 1994, 18:922-930

11. Gengler C, Guillou L: Solitary fibrous tumor and hemangiopericytoma: evolution of a concept. Histopathology 2006, 48:63-74

12. Martin JM, Jorda E, Calduch L, Monteagudo C, Pereda C, Villalon G: Self-healing generalized infantile myofibromatosis. J Eur Acad Dermatol Venereol 2008, 22:236-238

13. Fetsch JF, Miettinen M, Laskin WB, Michal M, Enzinger FM: A clinicopathologic study of 45 pediatric soft tissue tumors with an admixture of adipose tissue and fibroblastic elements, and a proposal for classification as lipofibromatosis. Am J Surg Pathol 2000, 24:1491-1500
14. Teo HE, Peh WC, Chan MY, Walford N: Infantile lipofibromatosis of the upper limb. Skeletal radiol 2005, 34:799-802

15. Henno S, Loeuillet L, Henry C, D’Hervé D, Azzis O, Ferrer J, Poulain P, Babut JM, Merlio JP, Jouan H, Dubus P: Cellular mesoblastic nephroma: morphologic, cytogenetic and molecular links with congenital fibrosarcoma. Pathol Res Pract 2003, 199:35-40

16. Cecchetto G, Carli M, Alaggio R, Dall'Igna P, Bisogno G, Scarzello G, Zanetti I, Durante G, Inserra A, Siracusa F, Guglielmi M, Italian Cooperative Group: Fibrosarcoma in pediatric patients: results of the Italian Cooperative Group studies (1979-1995). J Surg Oncol 2001, 78:225-231

17. Variend S, Bax NM, van Gorp J: Are infantile myofibromatosis, congenital fibrosarcoma and congenital hemangiopericytoma histogenetically related? Histopathology 1995, 26:57-62

18. Bourgeois JM, Knezevich SR, Mathers JA, Sorensen PH: Molecular detection of the ETV6-NTRK3 gene fusion differentiates congenital fibrosarcoma from other childhood spindle cell tumors. Am J Surg Pathol 2000, 24:937-946

19. Fisher C: Fibromatosis and fibrosarcoma in infancy and childhood. Eur J Cancer 1996, 32A:2094-2100

20. Leal N, Lopez JC, Diaz M, Ros Z, Perez Alonso P, Tovar J: Congenital Fibrosarcoma. Diagnostic-therapeutic implications. Cir Pediatr 2000, 13:156-158

21. Schofield DE, Fletcher JA, Grier HE, Yunis EJ: Fibrosarcoma in infants and children. Application of new techniques. Am J Surg Pathol 1994, 18:14-24

22. Flores-Stadler EM, Chou PM, Barquin N, Thanqavelu M, Gonzales-Crussi F: Fibrous tumors in children-a morphological and interphase cytogenetic analysis of problematic cases. Int J Oncol 2000, 17:433-437

23. Saiji E, Guillou L: Tumeurs fibroblastique et myofibroblastique de tete et du cou. Ann Pathol 2009, 29:335-346

24. Morotti RA, Legman MD, Kerkar N, Pawel BR, Sanger WG, Coffin CM: Pediatric inflammatory myofibroblastic tumor with late metastasis to the lung: case report and review of the literature. Pediatr Dev Pathol 2005, 8:224-229

25. Dehner LP: Inflammatory myofibroblastic tumor. The continued definition of one type of so-called inflammatory pseudotumor. Am J Surg Pathol 2004, 28:1652-1654

26. Cessna MH, Zhou H, Sanger WG, Perkins SL, Tripp S, Pickering D, Daines C, Coffin CM: Expression of ALK1 and p80 in inflammatory myofibroblastic tumor and its mesenchymal mimics: a study of 135 cases. Mod Pathol 2002, 15:931-938

27. Sukow WR, Cheville JC, Carlson AW, Shearer BM, Piatigorsky EJ, Grogg KL, Sebo TJ, Sinnwell JP, Ketterling RP: Utility of ALK1 protein expression and ALK rearrangements in distinguishing inflammatory myofibroblastic tumor from malignant spindle cell lesions of the urinary bladder. Mod Pathol 2007, 20:592-603

28. Tsuzuki T, Magi-Galluzzi C, Epstein JI: ALK-1 expression in inflammatory myofibroblastic tumor of the urinary bladder. Am J Surg Pathol 2004, 28:1609-1614 